\title{
CONSTRUCTION OF WHITENESS THROUGH NOMINATION, PREDICATION, ARGUMENTATION AND INTENSIFICATION OR MITIGATION
}

\author{
Shuv Raj Rana Bhat*
}

\begin{abstract}
In this paper, Mary Kingsley's Travels in West Africa has been analysed from the perspective of critical discourse analysis. In particular, how Kingsley constructs whiteness through strategies such as nomination, predication, argumentation and intensification or mitigation has been explored. The natives from minor culture are represented from the western terministic screens, to use K. Burke's phrase. The findings show that the strategies used are related to the positive construction of self (West) and the negative presentation of Other (Africa).
\end{abstract}

Key words: Nomination, predication, argumentation and intensification or mitigation.

\section{INTRODUCTION AND OBJECTIVE}

At the very outset of this paper, a question may arise as to why Kingsley's Travels in West Africa should be studied from the perspective of critical discourse analysis. Therefore, I would like to justify why critical discourse analysis is an appropriate theoretical lens to probe into travel writings such as Kinsley's Travels in West Africa prior to introducing critical discourse analysis. Commonly used as CDA, an abbreviated form, it has proved to be almost indispensable for my research, as it provides me with tools to examine the whole issue of language use by those in power from a different perspective. In particular, I have looked into the use of language from the perspective of the patient, to use semantic term and critically analyzed the language used by people in power who are responsible for maintaining hegemony in the society. A research without a critical eye on the way language - racist expression-is used in Travels in West Africa remains largely unexplored, incomplete and, therefore, unjustifiable. Critical discourse analysis provides a means of understanding how Kingsley's text is ideologically relevant in the nineteenth century. I side with Phadindra who believes in Wodak's contention that "texts are

* Mr. Bhat is PhD Scholar, University of Texas, EI Paso USA. 
often sites of struggle in that they show traces of differing discourses and ideologies all contending and struggling for dominance," and language as such, "provides a finely articulated vehicle for differences in power within hierarchical social structures" (Upadhyaya), (2010).

Nineteenth century European travel writings more often than not functions as a vehicle for colonial discourse, strategically representing nonEuropeans such as Asians and Africans in order to justify their subjugation, and their land as a site of opportunity. First published in 1897, Mary Kingsley's Travels in West Africa is no exception. I commence this paper with the contention that Travels in West Africa should be studied as a rhetorical text, that Kingsley's objective in depicting both the land and the people is to represent Africa inherently disponible, a term used by Mary Louise Pratt to indicate "available for improvement" through capitalism (Imperial Eyes $60)$. Working from this assertion, I use the concepts developed by Reisigl \& Ruth (2005) to explore the development of racialized constructions of African identity and their ideological relationship to disponibility.

\section{DISCUSSION}

Beginning in disciplines such as semiotics and linguistics, the term discourse plays an increasingly significant role in contemporary social science. It has been eclectically used to refer to language use, larger units of language such as paragraphs, conversations, interviews and specific systems of meaning which form the identities of subjects and objects. Theorists such as Jee (2011) go to such an extent as to distinguish "Discourse" with a capital "D" from "discourse" with a little "d." Jee (2011) uses "Discourse" with big " $D$ " to refer to:

Social languages [which] are varieties or styles of language used to enact specific socially situated identities and activities (practices) associated with those identities. But people enact identities not just through language, but by using language together with other "stuff" that isn't language. I use the term "Discourse," with a capital "D," for ways of combining and integrating language, actions, interactions, ways of thinking, believing, valuing, and using various symbols, tools, and objects to enact a particular sort of socially recognizable identity. (p. 201) Likewise, he reserves the word "discourse" with a little "d," "to mean language-in-use or stretches of language (like conversations or stories)" (34). Jee's (2011) capital "Discourse" as a way of thinking, believing, and valuing comes closer to Norman Fairclough's idea of discourse analysis which basically aims: to systematically explore often opaque relationships of causality and 
determination between (a) discursive practices, events and texts, and (b) wider social and cultural structures, relations and processes; to investigate how such practices, events and texts arise out of and are ideologically shaped by relations of power and struggles over power; and to explore how the opacity of these relationships between discourse and society is itself a factor securing power and hegemony (p. 135).

Norman Fairclough's discussion of the aim of discourse analysis as a way to explore opaque relationships between discursive practices and wider social and cultural structures shows his affinity with the idea of Wodak (2001). According to her, the primary objective of critical discourse analysis is to analyze, "opaque as well as transparent structural relationships of dominance, discrimination, power and control as manifested in language" (204). She further explains that critical discourse analysis "studies real and often extended instances of social interaction which take partially linguistic form. The critical approach is distinctive in its view of (a) the relationship between language and society, and (b) the relationship between analysis and the practices analysed" (173). Highlighting the way language gains its power, she repeats:

Language is not powerful on its own - it gains power by the use powerful people make of it. This explains why CDA often chooses the perspective of those who suffer, and critically analyzes the language use of those in power, who are responsible for the existence of inequalities and who also have the means and the opportunity to improve conditions. (p. 10). This obviously highlights the discursivity involved in discourses of travel writing and the subsequent impact on the people being represented. Given the nature and scope of this study, it is limited to the analysis of the racial issues in the nineteenth century England by picking five out of the many different linguistic or rhetorical means by which persons are discriminated against in a racist manner. To understand how racism is reproduced, we need to understand how it is constructed linguistically. Drawing on the extensive genealogy of discourse analytic approaches to textual analysis, most recently those related to critical discourse analysis and social inequality, practitioners of the critical discourse analysis have narrowed its focus with respect to racist discourse to the given questions:

How are persons named and referred to linguistically? What traits, characteristics, qualities and features are attributed to them? By means of what arguments and argumentation schemes do specific persons or social groups try to justify and legitimize the exclusion, discrimination, 
suppression and exploitation of others? From what perspective or point of view are these naming, attributions, and arguments expressed? Are the respective discriminating utterances articulated overtly, are they even intensified or are they mitigated? (Reisigl \& Wodak 2005, p. 44). Based on these, the discourse approach considers five types of strategies, all of which are related to the positive construction of Self and the negative presentation of Other. "Referential" or "nominational" strategies, are those "by which one constructs and represents social actors: for example ingroups and outgroups."(45). Reisigl \& Wodak (2005) indicate several ways this can occur, including "reference by tropes, biological, naturalizing and depersonalizing metaphors and metonymies, as well as by synecedoches in the form of a part standing for the whole ... or a whole standing in for the part ... (45). Because of the significance and prevalence of nomination strategies, this approach draws as well from the Theo Van Leeuwen's system network of representation, incorporating such categories as "passivization," "impersonalization," "collectivization," "backgrounding," and "objectivation" (pp. 46-47).

European names, derogative names, denial of the name and sexism are few of the many referential strategies by means of which writers like Kingsley (1897) exhibit their racist attitude towards the indigenous people of West Africa. The most fundamental form of rhetorical discrimination is that of identifying persons linguistically by naming them derogatively or vituperatively. Terminologies such as "nigger" and "savage" are more than sufficient to perform racist idea as they connotatively convey insulting meanings. Kingsley makes a profuse use of such terms in Travels in West Africa. In the very opening chapter entitled "Liverpool to Sierra Leone and the Gold Coast," Kingsley (1897) describes her journey by rickshaw which was being pulled by two Afro-Americans:

It was pulled in front by two government negroes and pushed behind by another pair, all neatly attired in white jackets and knee breeches, and crimson cummerbunds yards long, bound round their middles. Now it is an ingrained characteristic of the uneducated negro, that he cannot keep on a neat and complete garment of any kind. It does not matter what that garment may be; so long as it is whole, off it comes. (p. 12). In this quote, Kingsley (1897) uses the rhetoric of somatisation which is realized through repeated somatonym or linguistic item "negroes" in order to show their demeaning status. As a matter of fact, Kingsley's text is replete with racionyms such as "blacks," "bush negroes," bush-souls," and "darkskin." In chapter twelve, she refers to the natives as "the savage" to denote 
primitivity or lack of civilization (140). But when it comes to addressing people from her continent, she shows her great reverence. For example, the name Nassau appears in the text in different forms as "Dr. Nassau" or "The Rev. Dr. Nassau" (4). In the chapter sixteen titled "Ascent of the Great Peak of Cameroons," Kingsley refers to a group of local women in terms of mental deficiency, "those foolish creatures" (202). Some of the names Kingsley assigns to local people include "Smiles," "Gray Shirt," "Singlet," and "Pagan" which are based on physical appearances of superficial behavioral patterns rather than personality. These names actually reduce the African individuals nearly to objects. The only way for Kingsley to understand them is through the process of christening. She must put them in terms understandable to the Europeans, fitting them within a scheme that is knowable and acceptable within ethnocentric British ideology. In so doing, she denies their humanity. Sexist language can serve many different purposes on the side of the writers - psychological, social or political. "Linguistic exclusion," contend Reisigl \& Wodak (2005), "is not only strategically employed to conceal persons responsible for discriminatory activities, it has clearly discriminatory effects as in cases of sexist ignoring of women by not naming them" (47). Kingsley's (1897) use of reference items such as "man" and "he" (55) exclude women from their own male tribes. While Kingsley plays a feminine role while she is in England, she shows her masculine behavior in Africa. The fact that she is addressed as "sir" in Africa bears witness to this contention.

Closely related to reference, predicational strategies involve the use of "stereotypical, evaluative attributions of negative and positive traits in the linguistic form of implicit or explicit predicates" (45). It is noted that some of the nominating terms can have the effect of being evaluative because "the pure referential identification very often already involves a denotatively as well as a connotatively ... deprecatory or appreciative labeling of the social actors" (45). Predication is a process of assigning qualities to persons, animals, action and social phenomena. Predicational strategies are mainly realized by specific forms of reference, attributes, predicates, collocations, comparisons, similes, metaphors, synecdoches, metonymies, hyperboles and allusions. In the chapter XVII entitled "Ascent to the Great Peak of Cameroons," Kingsley describes a scene in which she becomes an object of gaze - the local people try to see her inside the room by pushing open the window shutters. But when she refers to them, she uses expressions such as "a mass of black heads" and "white teeth," a predicational strategy called synecdoche in which a part of something (black's white teeth and 
black heads) stands for the whole thing (black people). Likewise, Kingsley presents Smiles, a name christened by Kingsley herself and his friends as criminals: "frequent roll-calls were found necessary, so that crimes of Smiles and his fellows might not accumulate to an unmanageable extent" (240). The words "gang" and "liars" frequently occur in her narrative.

Argumentation strategies involve the way that the text functions persuasively. This study considers argumentation strategies in a narrower sense, primarily through the analysis of logical fallacies and topoi. Both of these lie at the heart of racist discourse, for "[i]f one looks at the structure of prejudices from an argumentation theoretical perspective, one can ascertain that in every racist, antisemitic, nationalist, ethnicist and sexist prejudice or stereotype there is inherent a fallacious generalisation" (Reisigl \& Wodak, 2005, p. 63). Frequently combined with fallacies, topoi are used to justify negative attributes, social and political inclusion and exclusion, and the "discrimination or preferential treatment of the respective persons or groups of persons" (45). Reisigl and Wodak cite the work of Kienpointetner in describing topoi as "parts of argumentation that belong to the obligatory, either explicit or inferable, premises. They are the content-related warrants or 'conclusion rules' that ... justify the transition from the argument or arguments to the conclusion" (qtd. in Discourse 74-75). A common topos cited is that of "advantage" or "usefulness," whereby if an action is considered useful or beneficial, then it should be undertaken (75). The topoi used in Travels in West Africatypically revolve around the need for change, such as the alleged "backwardness," of the people or the "ancient" condition of the territory, both geologically and culturally. Other topoi are subordinated to this main goal, focusing on more specific concerns such as the people's purportedly vice-ridden nature, lack of education, and unfitness for selfgovernance, to name just a few. In the following passage from "Trade and Labour in West Arica," Kingsley (1897) justifies why development of trade is necessary:

The development of trade is a necessary condition for the existence of the natives, and the discovery of products in the forests that will be marketable in Europe, and the making of plantations whose products will help to take the place of those he so recklessly now destroys, will give him a safer future than can any amount of abolitions of domestic slavery, or institutions of trial by jury, etc. If white control advances and plantations are not made and trade with the interior is not expanded, the condition of the West African will be a very wretched one, far worse than it was before the export slave-trade was suppressed. (p. 256) 
In the quote above, Kingsley creates a situation in which trade becomes indispensable for the survival of the indigenous people. As development of trade and plantation on the part of the natives are impossible, white intervention is a must for their rescue. Likewise, below is given a quote which is an extremely fallacious generalization: Keane says - 'their inherent mental inferiority, almost more marked than their physical characters, depends on physiological causes by which the intellectual faculties seem to be arrested before attaining their normal development'; and further on, 'We must necessarily infer that the development of the negro and white proceeds on different lines. While with the latter the volume of the brain grows with the expansion of the brain-pan; in the former the growth of the brain is on the contrary arrested by the premature closing of the cranial sutures, and lateral pressure of the frontal bone.' You will frequently meet with the statement that the negro child is as intelligent, or more so, than the white child, but that as soon as it passes beyond childhood it makes no further mental advance.

Burton says: 'His mental development is arrested, and thenceforth he grows backwards instead of forwards.' (p. 252). Keane represents the black people as if they do not belong to the human species. To show that they are different species, unlike the whites who are human species, he discusses the way anatomy and physiology of the blacks function - contrary to the mental development of the whites, the blacks grow backwards. This is an extreme example of fallacious argument based not on logic but on racism. Finally, "intensifying" or "mitigating" strategies are used to heighten or blunt the force of racist statements. Linguistically, they "qualify and modify the epistemic status of a proposition .... These strategies play an important role in the discursive presentation inasmuch as they operate upon it by sharpening it or toning it down" (Reisigl \& Wodak (2005), p. 45). Intensification and mitigation often occur through the degree of directness or explicitness by which the speaker utters a racist statement.

When Kingsley quotes in dialect the African speakers she meets, Africans are constructed as humorously primitive. For instance, one member of her party, whom she calls a "distinguished sportsman" for his ability to catch game, is quoted as describing his gaming practice thus: "You go shoot thing with gun. Berra well-buy you no get him thing for sure. No sah. Dem gun make nize. Berra well" (61). She further continues, "You fren hear demnize and come look him, and you hab to go share what you done kill. Or bad man hear him nize, and he come look him, and you go fit to get share-you fit to get kill yusself. Chii! chii! traps be best!" (61). 
While Kingsley gives lip service to praising the "distinguished sportsman" she also belittles him, mockingly representing (phonetically) his attempt at the English language. In other words, the expression "distinguished sportsman" appears to be genuine approbation, yet the eye dialect used by Kingsley presents such a vividly offensive image that the impact of the positive reference is negated, or "mitigated."

\section{CONCLUSION}

As the aforementioned analysis shows, critical discourse analysis (CDA) explicates abuses of power promoted by Travels in West Africa, by analyzing linguistic/semiotic details in light of the larger social and political contexts. It particularly exhibits Mary Kingsley's deployment of strategies such as nomination, predication, argumentation and intensification or mitigation in order to represent social actors especially African Bantu People and Kingsley herself. The findings show that language is no longer a neutral entity; it is rather ideologically charged. Kingsley's choice of diction, argument and conclusion show that she is an epitome of British imperialism that seeks to eliminate the identity and existence of the non-western people like Africans. Her abundance use of adjectives, politically incorrect words and her method of arriving at conclusion are of particular interest because they reek of racism and inequality. When it comes to addressing the white audience in her home country, Kingsley is very much selective in the use of words - honoured, powerful, intelligent and superior - that put them on a pedestal, clearly investing positive attitude in the language she uses.

\section{REFERENCES}

Jee P. (2011). An introduction to discourse analysis: Theory and method.

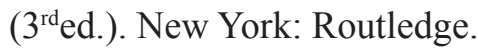

Kingsley, M. H. (1897). Travels in west Africa. London: Macmillan.

Reisigl, M. \& Wodak, R. (2005). Discourse and discrimination: Rhetorics of racism and anti-semitism. London: Routledge.

Upadhyaya, P. K. (2010). Politics of hegemony and denial in the rhetoric of language and education policy in Nepal: A critical discourse analysis of policy documents and government sponsored textbooks (1960-2009). An unpublished dissertation, University of Texas, Ann Arbor: UMI, 2010. 3433509.

Wodak, R. (2001). The discourse-historical approach. In methods of critical discourse analysis. An unpublished dissertation, London: Sage, 2001. 63-94. 